\title{
Pengaruh Produk \& Harga Terhadap Keputusan Pembelian Pada Konsumen Tas Merk Rumah Warna Di Bandar Lor Kota Kediri
}

\author{
Siti Mutmainah; Budi Rahayu; Marwita Andarini \\ Fakultas Ekonomi - Universitas Kadiri \\ E-mail : budir@unik-kediri.ac.id
}

\begin{abstract}
The study aims to see how much influence the product and price have on purchasing decisions for color house brand bags in Bandar Lor, Kediri. Methods of data collection using the method of observation, interviews, questionnaires and literature studies carried out based on systematic based on research methods. Data analysis using multiple linear regression methods were processed using SPSS assistance. The analysis phase starts from the normality test, validity test, hypothesis testing, $T$ test and $F$ test to see the effect of independent variables on the dependent variable simultaneously or partially with a confidence level of $95 \%(a=0.05)$. The results of the study prove that product variables and prices have a significant influence on purchasing decisions for color house brand bags in the city of Kediri simultaneously or partially. The value of determination coefficient is $90.3 \%$, so the purchasing decision on a bag of color house brands in Bandar Lor Kota Kediri is influenced by product variables and prices. The remaining $9.7 \%$ is influenced by other variables outside the research.
\end{abstract}

Key Words : Product, Price, Brand, Purchasing Decisions

\begin{abstract}
ABSTRAK
Penelitian bertujuan melihat seberapa besar pengaruh produk dan harga terhadap keputusan pembelian tas merk rumah warna di Bandar Lor kota Kediri. Metode pengumpulan data menggunakan metode observasi,wawancara, kuesioner dan studi kepustakaan yang dilakukakan berdasarkan sistematik berdasarkan metode penelitian. Data analisis menggunakan metode regresi linier berganda diolah dengan menggunakan bantuan SPSS tahapan analisa dimulai dari ujio normalitas, uji validitas, pengujian hipotesis, uji $T$ dan uji $F$ untuk melihat pengaruh variabel bebas terhadap variabel terikat secara simultan maupun parsial dengan tingkat kepercayaan $95 \%$ $(a=0,05)$. Hasil penelitian membuktikan bahwa variabel produk dan harga mempunyai pengaruh secara signifikan terhadap keputusan pembelian tas merk rumah warna di bandar lor kota kediri secara simultan maupun parsial. Nilai koefesien determinasi sebesar 90,3\% jadi keputusan pembelian terhadap tas merek rumah warna di Bandar Lor Kota Kediri dipengaruhi oleh variabel produk dan harga.Sisanya sebesar 9,7\% dipengaruhi variabel-variabel lainnya diluar penelitian.
\end{abstract}

Kata Kunci : Produk, Harga, Merek Dan Keputusan Pembelian

\section{PENDAHULUAN}

Permintaan pasar pada jenis pakaian dan aksesoris saat ini semakin meningkat karena dalam hitungan bulan tren pakaian dan aksesoris sudah berganti dengan yang baru. Di jaman globalisasi saat ini teknologi semakin canggih, kini semua kalangan bisa 
memperoleh informasi dari berbagai sumber sepeti TV, Hand Phone Aandroit dan internet. Semua orang dapat memperoleh informasi dengan cepat dan luas termasuk mengenai tren aksesoris dan produk fashion saat ini. Karena itu semua kalangan saling berebut untuk menyesuaikan diri dengan mode dan tren baru yang ada saat ini agar tidak ketinggalan mode.Kualitas pelayanan dan kualitas produk sangat bermanfaat (Afif, 2015)

Produk adalah barang atau jasa yang diperjual belikan atau bisa disebut sebagai hal yang diproduksi untuk kemudian ditawarkan kepada konsumen. Penghasilan konsumen atau pendapatan sesorang pembeli akan menentukan pilihan jenis barang dari kelompok mana yang akan dibelinya. Produk pada dasarnya adalah segala hal yang dapat dipasarkan dan yang dapat memuaskan konsumennya ketika di pakai atau digunakan.Dengan adanya air minum semua orang membutuhkan air untuk dikonsumsi setiap harinya yang merupakan kebutuhan pokok (Ruhamak, 2016)

Harga adalah nilai nominal yang dapat ditukarkan pembeli dengan manfaat yang dimiliki barang tersebut atau produk jasa yang digunakan oleh konsumen dan penjual melaui proses penawaran harga terhadap sesama pembeli. Keputusan pembelian terjadi secara tidak terduga misalnya hanya dengan melihat produk yang dipajang dipasar swalayan dengan harga diskon kemudian memutuskan untuk minat beli.

Salah satu objek pemasaran yang potensial bagi perusahaan adalah wanita dan tren fasion. Karena saat ini wanita digolongkan menjadi dua bagian. Yakni wanita domestik dan wanita karir. Sedangkan wanita karir adalah wanita yang memiliki penghasilan sendiri untuk memenuhi kebutuhan mereka tanpa harus bergantung pada penghasilan suami.

Rumah warna adalah home industri yang memproduksi berbagai macam produk unik dan kreatif salah satu produk utama mereka adalah tas tangan dan tas punggung. Produk rumah warna adalah produk karya anak bangsa yang merupakan produk lokal dan original.

Rumah warna di bandar lor kota kediri pertama kali muncul pada tahun 2008 kala itu bertempat di pusat perbelanjaan sri ratu dengan memakai tanah ukuran 5 meter persegi. Pada tahun 2013 lokasi berpindah tempat di kediri town square (ketos) masih tetap menggunakan tanah dengan ukuran 6 meter persegi namun dengan konsep desain yang baru. Seiring bertambahnya barang dan kebutuhan tempat yang lebih besar, maka 
pada tahun 2016 tepatnya tanggal 1 desember 2016 rumah warna kediri berpindah tempat lagi dan menggunakan ruko yang berlokasi di bardar hingga sekarang.

Rumah warna di bandar lor satu managemen dengan rumah warna di tulunganggung rumah warna sendiri telah tersebar ke berbagai wilayah di jawa timur seperti tulungagung, kediri, surabaya . Rumah warna sebenarnya berasal dari yogyakarta memulai usaha ini dengan berawal dari usaha kecil dengan produk utamanya tas dan frame. Kini berkat ide kreatif dari tim rumah warna menjadi berkembang hingga sekarang dan sudah memiliki cabang di berbagai wilayah. Di jawa tengah sendiri rumah warna merupakan produk yang sangat terkenal karena telah digemari oleh berbagai masyarakat terutama anak muda. Selain itu rumah warna juga telah mendapat kepercayaan dari berbagai pihak karena memiliki produk berkualitas bergaransi dan bangga karena produk lokal karya anak bangsa. Dari uraian diatas dapat dilakukan penelitian mengenai Pengaruh produk dan harga terhadap keputusan pembelian (Studi kasus pada konsumen tas merk rumah warna di bandar lor kota kediri).

\section{TINJAUAN PUSTAKA}

\section{Penelitian Terdahulu}

1. Asih fatmawati S (2016) Judul : Pengaruh citra merek, kualitas produk, dan harga terhadap keputusan pembelian produk tas dan sepatu charles dan keith (studi kasus konsumen charles dan keith paragon semarang).

Variabel dan alat analisis : Jenis penelitian : menggunakan metode accidental sampling.Variabel : 1.citra merek 2.kualitas produk3.harga 4.keputusan pembelian Analisis data : Regresi linier berganda

Hasil kesimpulan : Citra merek berpengaruh positif terhadap keputusan pembelian dan memberi sumbangan terhadap 17,6\%.Kualitas produk berpengaruh positif terhadap keputusan pembelian dan memberi sumbangan sebesar 23,4\% pada keputusan pembelian.Harga berpengaruh positif terhadap keputusan pembelian dan memberi sumbangan sebesar $21,4 \%$ pada keputusan pembelian.

2. Anastasa devi k (2015) Judul Penelitian : Pengaruh citra merek, harga dan gaya hidup terhadap keputusan pembelian produk imitasi (studi kasus pembelian tas 
imitasi louis vuitton pada mahasiswa fakultas ilmu sosial dan ilmu politik universitas diponegoro).

Variabel dan alat analisis : Jenis penelitian : deskriptif .Variabel :1.citra merek.2.harga 3.gaya hidup 4.keputusan pembelian

Analisis data: Regresi linier berganda

Hasil Kesimpulan : Dari ketiga variabel pula diperoleh hasil bahwa variabel harga berpengaruh kuat terhadap keputusan pembelian. Hal ini berarti variabel harga berpengaruh paling besar terhadap keputusan pembelian produk tas imitasi merek Louis Vuitton.

3. Leonardo budi hasiolan (2016) Judul Penelitian : Pengaruh kualitas produk, harga dan promosi terhadap keputusan pembelian produk johnson and johnson indonesia.

Variabel dan alat analisis : Jenis penelitian : kualitatif.Variabel : 1.kualitas produk 2.harga 3.promosi 4.keputusan pembelian

Analisis data : regresi linier berganda

Hasil Kesimpulan : Dari hasil pengujian menunjukkan bahwa dari semua variabel independen (promosi,harga dan desain) itu berpengaruh terhadap keputusan pembelian.

\section{Pengertian Produk}

Menurut (Lupiyoadi,2010:28) produk yang semuanya merupakan konsep proses yang dapat memberikan sejumlah nilai kegunaan bagi konsumen. Menurut (Lupiyoadi,2010:28) Keseluruhan konsep yang memberikan sejumlah nilai manfaat kepada konsumen.sedangkan menurut (Kotler\&Keller,2012:4) Produk adalah semua yang dapat ditawarkan di pasar untuk memenuhi apa yang kebutuhan oleh konsumen.

Pengembangan produk diperlukan pengetahuan bagi perusahaan mengenai tingkatan produk. (Kotler\&Keller,2012:4) 5 produk tingkatan :Tingkatan dasar, Tingkatan kedua, Tingkatan ketiga ,Tingkatan keempat, Tingkatan terakhir.

(Kotler\&Keller,2012:6) mengklasifikasikan produk yang terdiri dari :

1) Produk konsumen

a. Barang sehari-hari

Pembelian pelanggan mempunyai frekuensi tinggi dalam waktu cepat dan untuk memperolehnya tidak membutuhkan upaya terlalu banyak. 
b. Barang belanjaan

Produk dibagi menjadi dua yaitu: Produk homogen adalah produk yang mempunyai mutu sama tetapi harganya cukup berbeda dan produk heterogen adalah produk yang mana bagi konsumen paling manfaat itu adalah berharga dari pandanganya.

c. Barang khusus

Produk yang memiliki karakteristik istimewa atau unik sehingga pelanggan mau membayarnya dengan harga tinggi dan rela mengorbankan waktu dan tenaga untuk memperolehnya.

d. Barang yang tidak dicari

Produk yang keberadaannya dan juga kemanfaatannya tidak banyak diketahui oleh konsumen.

\section{Pengertian Harga}

Menurut (Kotler\&Armstrong,2013:151) Sejumlah uang yang dibayar suatu barang atau jasa nilai uangnya dapat ditukar konsumen karena memiliki guna produk atau jasa. Menurut (Kotler,2012:132): Harga adalah jumlah uang yang harus dibayar pelanggan untuk produk itu.

Menurut kebijakan mengenai harga sifatnya sementara mengikuti perkembangan harga dipasar juga harus mengetahui posisi perusahaan pada situasi pasar secara keseluruhan. elemen bauran pemasaran yang berhubungan dimensi strategi harga :

1) Harga merupakan penyataan nilai dari suatu produk .

2) Harga merupakan aspek yang tampak jelas bagi para pembeli.

3) Harga adalah determinan untuk permintaan. Berdasarkan hukum permintaan

4) Harga berkaitan langsung dengan pendapatan dan laba.

5) Harga bersifat fleksibel, artinya bisa disesuaikan dengan cepat.

6) Harga mempengaruhi citra dan positioning.

7) Harga merupakan masalah nomor satu yang dihadapi para manajer.

empat tujuan penetapan harga yaitu: berorientasi mendapatkan Laba, beroriantasi volume, berorientasi citra, stabilitas harga .

Menurut (Saladin,2011:95) strategi kebijakan harga adalah suatu yang di ambil keputusan mengenai harga yang telah di tetapkan pihak managemen.Tujuan strategi 
penetapan kebijakan harga oleh perusahaan: Profit Maximalization Pricing,Market Share Pricing, Market Skimming Price, Current Revenue Pricing.Target Profit Pricing, Promotional Pricing.

Metode penetapan harga empat kategori utama yaitu metode penetapan harga berbasis permintaan, berbasisi biaya, berbasis laba, dan berbasis persaingan. Menurut (Kotler\&Keller,2012:77) metode penetapan harga:

1. Metode Penetapan Harga Berbasis Permintaan

2. Metode Penetapan Harga Berbasis Biaya

3. Metode Penetapan Harga Berbasis Laba

4. Metode Penetapan Harga Berbasis Persaingan.

Menurut (Kotler\&Armstrong,2012:52) unsur utama dari variabel harga yaitu daftar harga, diskon, potongan harga, dan periode pembayaran. Menurut (Kotler \& Armstrong, 2012:278) empat indikator harga yaitu: Keterjangkauan harga,Kesesuaian harga dengan kualitas produk, Daya saing harga,Kesesuaian harga dengan manfaat.

\section{Pengertian Keputusan Pembelian}

Komponen utama pada prilaku konsumen adalah keputusan pembelian. Keputusan pembelian konsumen ada beberapa tahap demi tahap yang digunakan ketika membeli barang dan jasa. (Lamb,2008:23). Menurut (Schiffman\&Kanuk,2009:112), keputusan pembelian yaitu pemilihan dari dua atau lebih alternatif pilihan keputusan pembelian, artinya bahwa seseorang bisa membuat keputusan, harus tersedia beberapa alternatif pilihan. Keputusan tersebut itu dilakukan.

Menurut (Kotler\&Keller,2016:195) proses keputusan pembelian lima tahap yaitu : Pengenalan Masalah, Pencarian Informasi, Evaluasi Alternatif, Keputusan Pembelian, Perilaku Pasca Pembelian. Menurut (Swastha\&Handoko,2011) peran individu dalam sebuah keputusan membeli yaitu :

1. Pengambilan inisiatif

2. Orang yang mempengaruhi

3. Pembuat keputusan

Menurut (Kotler\&Armstrong,2012:135) perilaku konsumen dipengaruhi oleh : 1.Faktor budaya :Sub Budaya budaya,Kelas Sosial, Faktor Sosial Kelompok Referensi.2. Keluarga : Peran dan Status ,Faktor Pribadi, Faktor Psikologi . 
Kesimpulan di atas diindikasi banyak faktor mempengaruhi perilaku konsumen dalam melakukan keputusan pembelian pada faktor eksternal dan faktor internal berpengaruh faktor pribadi dan psikologi.

\section{Kerangka berpikir}

Skema jalannya pemikiran perlu di kemukakan untuk jalnnya menunjukkan arah dari penelitian dan mempermudah pemahaman dan penganalisaan masalah.

\section{Gambar 1 : Kerangka Berfikir}

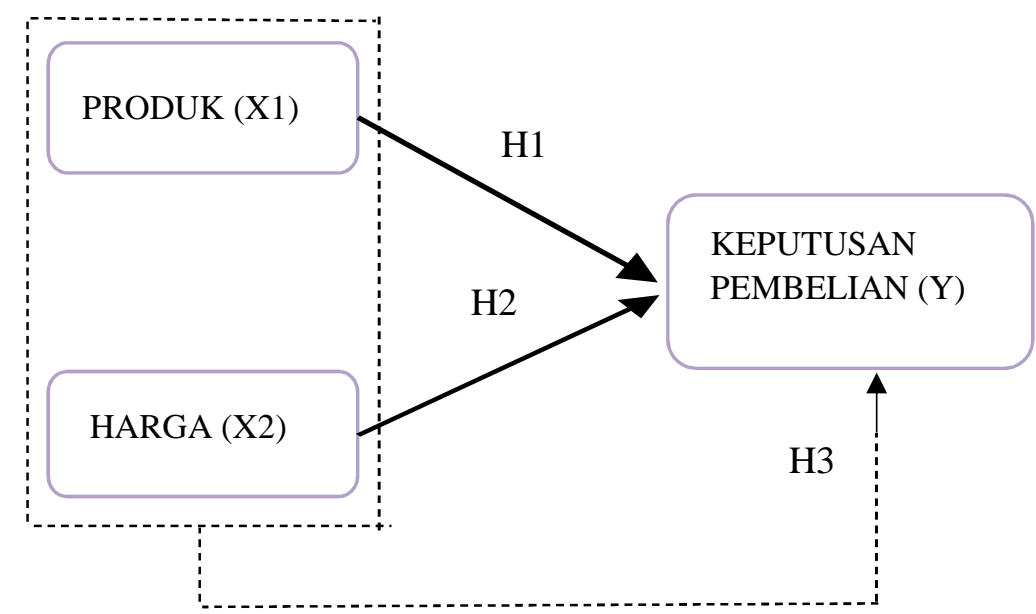

Sumber : (kotler,2015)

Keterangan :

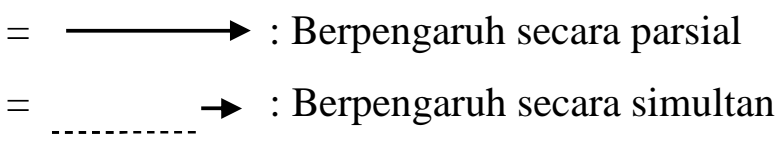

\section{Hipotesis}

Hipotesis adalah penelitian yang memakai pendekatan kuantitatif (Sugiyono,2014:64). Hipotesis ini dimaksudkan untuk memberi arah bagi analisis penelitian. Berdasarkan kerangka konsep di atas maka dapat dirumuskan hoipotesis sebagai berikut :

1. H1 : Ada pengaruh produk secara parsial terhadap keputusan pembelian pada tas merk rumah warna di bandar lor kota kediri.

2. $\mathrm{H} 2$ : Ada pengaruh harga secara parsial terhadap keputusan pembelian tas merk rumah warna di bandar lor kota kediri. 
3. H3 : Ada pengaruh secara simultasn produk dan harga terhadap keputusan pembelian tas merk rumah warna di bandar lor kota kediri.

\section{METODE PENELITIAN}

\section{Populasi}

Semua pembeli yang datang di toko tas merk rumah warna bandar lor kota kediri.

\section{Metode Pengambilan Sampel}

Adapun penentuan jumlah sampel yang dikembangkan oleh Rescoe dalam (Sugiyono,2011:130) yaitu bila dalam penelitian akan melakukan analisis dengan korelasi atau regresi berganda maka jumlah anggota sampel minimal 10 kali variabel maka jumlah anggota sampel $10 \times 3$ variabel $=30$ orang.

\section{Variabel Penelitian,Cara Pengukuran Dan Definisi Operasional Variabel Penelitian \\ a. Variabel Bebas Harga (X1) dan Produk (X2). \\ b. Variabel Terikat Keputusan pembelian ( Y )}

\section{Cara Pengukuran}

penelitian ini menggunakan kuesioner yang nantinya akan diisi oleh responden dengan menggunakan skala likert. Berupa pertanyaan yang jawabannya berbentuk skala deskriptif. Responden memberi tanda chek list $(\sqrt{ })$ pada kolom jawaban yang telah disediakan. Untuk analisis maka ditetapkan jawaban dari masing-masing responden untuk masing-masing mendapatkan skor. Berikut bobot penilaian skala likert.

\section{Cara Pengukuran}

SS sangat setuju bobot 5,S setuju bobor 4,KS kurang setuju bobot 3,TS tidak setuju bobot 2, STS sangat tidak setuju bobot 1 .

\section{Definisi Operasional Variabel}

1.Variabel Produk ( X1)

Indikator : Merk, Kualitas, Desain Jaminan. Skala : Likert 
2.Variabel : Harga (X2)

Definisi : Sejumlah nilai yang diperlukan untuk memperoleh suatu produk

Indikator : kesesuaian harga dengan kualitas,potongan harga, daya saing harga dengan produk sejenis. Skala:Likert

3.Variabel : Keputusan pembelian ( Y)

Definisi : Sikap atau tindakan yang dilakukan konsumen dalam menentukan pilihan dari beberapa produk yang akan digunakannya

Indokator : Pemenuhan kebutuhan,pencarian informasi, keunggulan dan kelemahan produk,keputusan pemilihan,keinginan untuk berpindah. Skala :Likert

\section{Metode Pengumpulan Data}
a. Wawancara,
b. Kuesioner
c. Observasi

Pengamatan langsung di obyek penelitian hal ini dilakukan guna mendukung hasil kuesioner dan wawancara.

\section{Uji Instrumen Penelitian}

Instrumen yang baik harus memenuhi dua persyaratan penting yaitu valid dan reliabel. Oleh karena itu angket harus diuji kevaliditasan dan kereliabilitasan terlebih dahulu sebelum digunakan. Dalam peneliti mengambil 30 responden untuk mengisi kuesioner (angket).

1. Uji Validitas

Valid jika $\mathrm{r}$ hitung mempunyai validitas lebih besar dari $>\mathrm{r}$ tabel tingkat signifikansi $5 \%$ dan nilai $r$ positif valid.

\section{Uji Reliabilitas}

Jika hasilnya $\alpha>0,06$ maka dinyatakan bahwa istrument tersebut reliabilitasnya tinggi .

\section{Metode Analisis Data}

analisis regresi linier berganda menggunakan rumus :

$\mathbf{Y}=\mathbf{a}+\mathbf{b}_{1} \mathbf{X}_{1}+\mathbf{b}_{2} \mathbf{X}_{2}$ 
Keterangan :

$\mathrm{Y} \quad=$ keputusan pembelian

a $\quad=$ konstanta

$\mathrm{b}_{1}, \mathrm{~b}_{2}=$ Regresi berganda

$\mathrm{X}_{1} \quad=$ Produk

$\mathrm{X}_{2}=$ Harga

\section{Uji Normalitas}

a. Jika probabilitas $>0,05$ maka distribusi dari populasi adalah normal

b. Jika probabilitas $<0,05$ maka populasi tidak berdistribusi secara normal Pengujian secara visual dapat juga dilakukan dengan metode gambar normal Probability Plots dalam program SPSS.

\section{Pengujian Hipotesis}

Hipotesis yang akan diuji dan dibuktikan dalam penelitian ini berkaitan dengan ada/tidaknya pengaruh variabel bebas. Hipotesis nol (Ho) menyatakan koefisien korelasinya tidak berarti/tidak signifikan, sedangkan hipotesis alternatif (Ha) menyatakan bahwa koefisien korelasinya.

1. Uji signifikan simultan (Uji F)

Pengujian dilakukan dengan uji parameter $\beta$ (uji korelasi) uji F-statistik. Menurut (Sugiyono,2013:257) dirumuskan sebagai berikut:

$\mathrm{H}_{0}$ : Signifikansi $\mathrm{F}>0,05$ dan $\mathrm{F}_{\text {hitung }}<\mathrm{F}_{\text {tabel, }} \mathrm{H}_{0}$ diterima hipotesis ditolak, artinya variabel produk $\left(\mathrm{X}_{1}\right)$, harga $\left(\mathrm{X}_{2}\right)$, Keputusan pembelian $(\mathrm{Y})$ tidak berpengaruh signifikan

$\mathrm{H}_{\mathrm{a}}$ : Signifikansi $\mathrm{F}<0,05$ dan $\mathrm{F}_{\text {hitung }}>\mathrm{F}_{\text {tabel, }} \mathrm{H}_{0}$ ditolak hipotesis diterima, artinya variabel produk $\left(\mathrm{X}_{1}\right)$, harga $\left(\mathrm{X}_{2}\right)$, keputusan pembelian $(\mathrm{Y})$ berpengaruh signifikan.

Bila $H_{0}$ diterima, maka dapat diartikan bahwa signifikannya suatu pengaruh variabel independen $H_{0}$ Berpengaruh signifikan dari variabel independen secara sama terhadap suatu variabel dependen.

2. Uji signifikan parsial 
Hal ini membuktikan apakah terdapat pengaruh antara masing-masing variabel independen (X) dan variabel dependen (Y). Menurut (Sugiyono,2013:250) menggunakan rumus:

$$
t=\frac{r \sqrt{n-2}}{\sqrt{1-r^{2}}}
$$

Keterangan:

$$
\begin{aligned}
& t=\text { Nilai uji } t \\
& r=\text { Koefisien korelasi pearson } \\
& r^{2}=\text { Koefisien determinasi } \\
& n=\text { Jumlah sampel }
\end{aligned}
$$

Hasil perhitungan ini selanjutnya dibandingkan dengan $t_{t \ell}$ dengan menggunakan tingkat kesalahan 0,05 uji dua pihak dan $d k=n-2$, kriteria sebagai berikut:

- $\quad H 0$ diterima bila $t_{h i t}<t_{t_{l}}$ atau $-t_{h} i t \quad>-t_{t_{1}}$

$$
\text { - } \quad H 0 \text { ditolak bila } t_{h} i t \quad>t_{t \iota} \text { atau }-t_{h} i t<-t_{t}
$$

Jika hasil pengujian statistik menunjukkan $H_{0}$ ditolak, maka berarti variabelvariabel independen secara parsial mempunyai pengaruh signifikan. hipotesis ini penulis menggunakan uji signifikan atau uji parameter $r$, maksudnya untuk menguji tingkat signifikansi maka harus dilakukan pengujian parameter $\mathrm{r}$.

3. Uji koefesien Determinasi $\left(\mathrm{R}_{2}\right)$

Koefisien determinasi menjelaskan proporsi variasi dalam variabel dependen $(Y)$ yang dijelaskan oleh variabel independen: $X_{i} ; i=1,2,3,4$, dst.) secara bersama-sama.

Sementara itu $R$ adalah koefisien korelasi majemuk yang mengukur tingkat hubungan antara variabel dependen $(Y)$ dengan semua variabel independen yang menjelaskan secara bersama-sama dan nilainya selalu positif. Selanjutnya untuk melakukan koefisien determinasi (adjusted $R^{2}$ ) untuk mengukur proporsi atau presentase sumbangan variabel independen yang diteliti terhadap variasi naik turunnya variabel dependen.

Rumus koefisien determinasi:

$K=R^{2} X 100 \%$

Keterangan:

$K=$ Besar atau jumlah koefisien determinasi 
$R^{2}=$ Nilai koefisien korelasi

\section{HASIL DAN PEMBAHASAN}

\section{Sejarah Singkat Rumah Warna}

Penelitian dilakukan di Rumah Warna di Jln.KH.wachid hasyim no.81,Bandar lor, mojoroto, kota kediri, jawa timur 64114. Yaitu suatu home industri kreatif yang memproduksi berbagai produk unik dan salah satu produk unggulan mereka adalah tas tangan dan tas punggung. Rumah warna di bandar lor kota kediri pertama kali muncul pada tahun 2008, dulu bertempat di pusat perbelanjaan sri ratu dengan memakai tanah ukuran 5 meter persegi. Pada tahun 2013 lokasi berpindah tempat di kediri town square (ketos) masih tetap menggunakan tanah dengan ukuran 6 meter persegi namun dengan konsep desain yang baru. Seiring bertambahnya barang dan kebutuhan, maka pada tahun 2016 tanggal 1 desember 2016 Rumah Warna kediri berpindah tempat di bardar lor sampai sekarang. Rumah warna di bandar lor satu managemen dengan rumah warna yang ada di tulunganggung rumah warna sendiri mempunyai cabang di berbagai wilayah di jawa timur seperti tulungagung, kediri, surabaya dll.

Pusat Rumah Warna berada di jawa tengah di yogyakarta. Tahun 2008 mulai berproduksi secara besar dan berlokasi di Jln. andean Sari no.8 Condong Catur Yogyakarta.

\section{Hasil Penelitian}

\section{Uji Instrumen}

Uji instrumen mengetahui kualitas instrumen digunakan dalam penelitian. Instrumen yang baik harus memenuhi dua persyaratan penting yaitu valid dan reliabel. Oleh karena itu angket harus diuji kevaliditasan dan ke reliabilitasan terlebih dahulu sebelum digunakan. Dalam uji validitas dan uji reliabilitas menggunakan progam SPSS versi 22 for windows.

\section{Uji Validitas}

Uji signifikansi dilakukan dengan menggunakan $r$ tabel. Nilai $r$ tabel untuk sampel 30 dengan tingkat signifikansi $5 \%$ menunjukkan $r$ tabel sebesar 0,361 . 


\begin{tabular}{|c|c|c|c|c|c|}
\hline Variabel & $\begin{array}{c}\text { Indikator } \\
\text { Pertanyaan }\end{array}$ & $\begin{array}{c}\text { Corrected } \\
\text { Item-Total } \\
\text { Correlation (r Hitung) }\end{array}$ & $><$ & $r$ tabel & Keterangan \\
\hline \multirow[t]{5}{*}{ Produk $\left(\mathrm{X}_{1}\right)$} & $\mathrm{X} 1.1$ & 0,895 & $>$ & 0,361 & Valid \\
\hline & $\mathrm{X} 1.2$ & 0,683 & $>$ & 0,361 & Valid \\
\hline & $\mathrm{X} 1.3$ & 0,759 & $>$ & 0,361 & Valid \\
\hline & $\mathrm{X} 1.4$ & 0,675 & $>$ & 0,361 & Valid \\
\hline & $\mathrm{X} 1.5$ & 0,729 & $>$ & 0,361 & Valid \\
\hline \multirow[t]{5}{*}{ Harga $\quad\left(X_{2}\right)$} & $\mathrm{X} 2.1$ & 0,901 & $>$ & 0,361 & Valid \\
\hline & $\mathrm{X} 2.2$ & 0,550 & $>$ & 0,361 & Valid \\
\hline & $\mathrm{X} 2.3$ & 0,649 & $>$ & 0,361 & Valid \\
\hline & $\mathrm{X} 2.4$ & 0,631 & $>$ & 0,361 & Valid \\
\hline & $\mathrm{X} 2.5$ & 0,785 & $>$ & 0,361 & Valid \\
\hline \multirow{5}{*}{$\begin{array}{l}\text { Keputusan } \\
\text { pembelian }\left(\mathrm{Y}_{3}\right)\end{array}$} & Y3.1 & 0,917 & $>$ & 0,361 & Valid \\
\hline & Y3.2 & 0,541 & $>$ & 0,361 & Valid \\
\hline & Y3.3 & 0,670 & $>$ & 0,361 & Valid \\
\hline & Y3.4 & 0,664 & $>$ & 0,361 & Valid \\
\hline & Y3.5 & 0,736 & $>$ & 0,361 & Valid \\
\hline
\end{tabular}

Sumber : Data Primer Yang Diolah (2019).

\section{Uji Realibilitas}

Variabel dikatakan reliabel jika memberikan nilai Cronbach Alpha lebih besar $>$ dari 0,6. Berikut ini adalah hasil uji reliabilitas :

Reliability Statistics

\begin{tabular}{|l|l|}
\hline Cronbach's Alpha & N of Items \\
\hline, 945 & 15 \\
\hline
\end{tabular}

Sumber : Data Diolah (2019) 
Item-Total Statistics

\begin{tabular}{|c|c|c|c|c|}
\hline & $\begin{array}{l}\text { Scale Mean if Item } \\
\text { Deleted }\end{array}$ & $\begin{array}{l}\text { Scale Variance if } \\
\text { Item Deleted }\end{array}$ & $\begin{array}{l}\text { Corrected Item- } \\
\text { Total Correlation }\end{array}$ & $\begin{array}{l}\text { Cronbach's Alpha if } \\
\text { Item Deleted }\end{array}$ \\
\hline$x 1.1$ & 47,3667 & 93,137 & ,906 & ,935 \\
\hline$x 1.2$ & 46,9667 & 106,102 & ,550 & ,944 \\
\hline$x 1.3$ & 47,5667 & 103,082 & ,659 & ,942 \\
\hline$x 1.4$ & 46,9333 & 106,064 & ,631 & ,943 \\
\hline$x 1.5$ & 46,9667 & 104,930 & ,763 & ,941 \\
\hline$x 2.1$ & 47,0667 & 92,961 & ,871 & ,937 \\
\hline$x 2.2$ & 47,2000 & 93,959 & ,881 & ,936 \\
\hline$x 2.3$ & 47,1667 & 96,557 & ,800 & ,939 \\
\hline$x 2.4$ & 46,9333 & 107,857 & ,548 & ,944 \\
\hline$x 2.5$ & 47,1667 & 107,868 & ,564 & ,944 \\
\hline y3.1 & 47,2000 & 99,545 & ,788 & ,939 \\
\hline y3.2 & 47,3667 & 100,378 & ,755 & ,940 \\
\hline y3.3 & 47,1667 & 104,213 &, 584 & ,944 \\
\hline y3.4 & 46,8333 & 100,557 & ,758 & ,940 \\
\hline y3.5 & 47,1000 & 105,197 & ,577 & ,944 \\
\hline
\end{tabular}

reliabel mempunyai nilai cronbach's alpha lebih besar > dari 0,6.

\section{Analisis Regresi Berganda}

regresi linier berganda menggunakan progam SPSS Versi 22 For Windows. analisis data digunakan uji normalitas, uji hipotesis, uji $\mathrm{T}$, uji $\mathrm{F}$ dan koefesien determinasi $R^{2}$. Maka diperoleh hasil seperti tabel dibawah ini :

\section{Coefficients ${ }^{a}$}

\begin{tabular}{|c|c|c|c|c|c|c|}
\hline \multirow{2}{*}{\multicolumn{2}{|c|}{ Model }} & \multicolumn{2}{|c|}{ Unstandardized Coefficients } & \multirow{2}{*}{$\begin{array}{l}\text { Standardized } \\
\text { Coefficients } \\
\text { Beta }\end{array}$} & \multirow[b]{2}{*}{$\mathrm{t}$} & \multirow[b]{2}{*}{ Sig. } \\
\hline & & B & Std. Error & & & \\
\hline \multirow[t]{3}{*}{1} & (Constant) & 1,098 & 1,107 & & ,992 & ,330 \\
\hline & Produk &, 551 & , 171 &, 524 & 3,225 & 003 \\
\hline & Harga & ,385 & 141 & ,444 & 2,731 & 011 \\
\hline
\end{tabular}

a. Dependent Variable: keputusan pembelian Sumber : Hasil Output Data (2019) 
Sehingga dari persamaan rumus regresi berganda dapat diperoleh hasil sebagai berikut :

\section{$Y=1,098+0,551 \times 1+0,358 \times 2$}

Keterangan :

$\mathrm{Y} \quad=$ keputusan pembelian

a $\quad=$ konstanta

$\mathrm{b}_{1}, \mathrm{~b}_{2}=$ Regresi berganda

$\mathrm{X}_{1} \quad=$ Produk

$\mathrm{X}_{2}=$ Harga

Berdasarkan persamaan yang diperoleh pada variabel produk nilai beta 0,524 , lebih besar > dari signifikan 0,003 variabel harga nilai beta 0,444 lebih besar > dari nilai signifikan 0,011 .

\section{Uji Normalitas}

One-Sample Kolmogorov-Smirnov Test

\begin{tabular}{|ll|l|}
\hline & & $\begin{array}{l}\text { Unstandardized } \\
\text { Residual }\end{array}$ \\
\hline $\mathrm{N}$ & & 30 \\
Normal Parameters ${ }^{\mathrm{a}, \mathrm{b}}$ & Mean &, 0000000 \\
& Std. Deviation & 1,10748962 \\
Most Extreme Differences & Absolute &, 131 \\
& Positive &, 104 \\
& Negative &,- 131 \\
Test Statistic & &, 131 \\
Asymp. Sig. (2-tailed) & &, $199^{c}$ \\
\hline
\end{tabular}
a. Test distribution is Normal.
b. Calculated from data.
c. Lilliefors Significance Correction.
Sumber : Data Output Diolah (2019) 
nilai signifikan sebesar 0,131 lebih besar > dari 0,05.

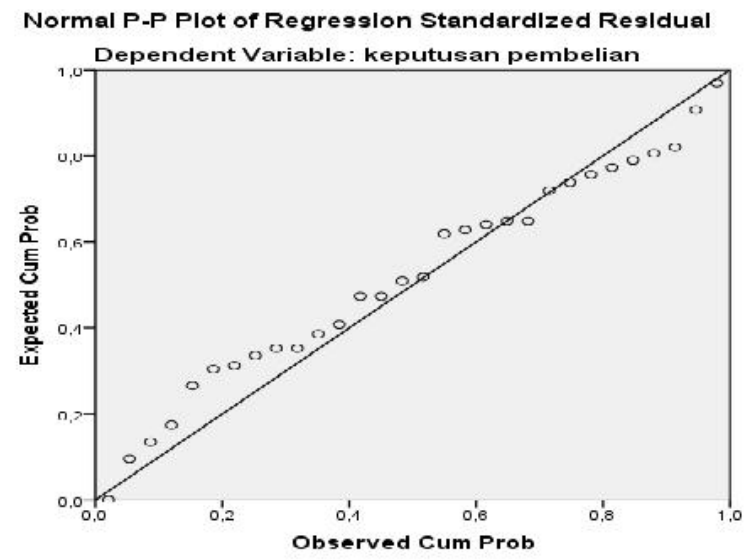

Sumber : output data diolah (2019)

Gambar tersebut menunjukkan bahwa titik-titik residual model regresi sudah berkompetensi normal.

\section{Uji T}

1. Nilai signifikan lebih kecil < dari 0,05 t hitung lebih besar $>$ dari t tabel berdapat pengaruh variabel $\mathrm{X}$ terhadap variabel $\mathrm{Y}$.

2. Nilai signifikan lebih besar $>$ dari $0,05 \mathrm{t}$ hituing lebih kecil < dari $\mathrm{t}$ tabel tidak berpengaruh variabel $\mathrm{X}$ terhadap variabel $\mathrm{Y}$.

\begin{tabular}{|c|c|c|c|c|c|c|}
\hline \multicolumn{7}{|c|}{ Coefficients $^{a}$} \\
\hline \multirow{2}{*}{\multicolumn{2}{|c|}{ Model }} & \multicolumn{2}{|c|}{ Unstandardized Coefficients } & \multirow{2}{*}{\begin{tabular}{|l} 
Standardized \\
Coefficients \\
Beta
\end{tabular}} & \multirow[b]{2}{*}{$\mathrm{T}$} & \multirow[b]{2}{*}{ Sig. } \\
\hline & & $B$ & Std. Error & & & \\
\hline 1 & (Constant) & 1,098 & 1,107 & & ,992 & ,330 \\
\hline & Produk &, 551 & 171 &, 524 & 3,225 &, 003 \\
\hline & Harga & ,385 &, 141 &, 444 & 2,731 &, 011 \\
\hline
\end{tabular}

a. Dependent Variable: keputusan pembelian

Sumber : Data Diolah Peneliti (2019)

a. Pengujian hipotesis pertama (H1)

Diketaui nilai signifikan untuk pengaruh produk X1 0,003 < 0,05 nilai T hitung 3,225> T tabel 2,052.

b. Pengujian hipotesis kedua ( $\mathrm{H} 2)$

Diketaui nilai signifikan X2 sebesar 0,011 <0,05 nilai T hitung 2,731 lebih besar $>$ dari T tabel 2,052. 


\section{Uji F}

1. Jika nilai signifikan lebih kecil $<$ dari 0,05 atau $\mathrm{F}$ hitung lebih besar $>$ dari $\mathrm{F}$ tabel berpengaruh variabel X1 dan X2 secara simultan terhadap variabel $\mathrm{Y}$.

2. Nilai signifikan lebih besar $>$ dari 0,05 atau $F$ hitung lebih kecil < dari $F$ tabel tidak berpengaruh variabel X1 dan X2 secara simultan terhadap variabel Y.

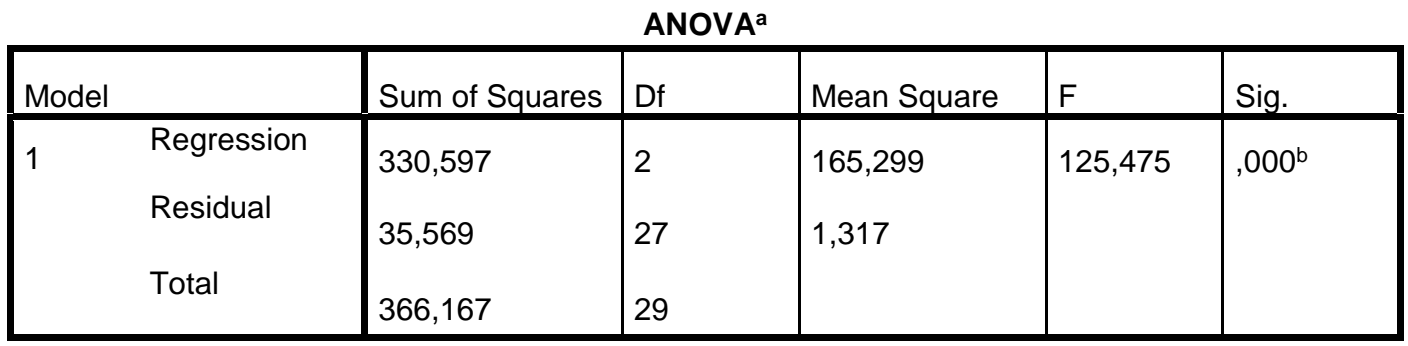

a. Dependent Variable: keputusan pembelian

b. Predictors: (Constant), harga, produk

Sumber : Data Diolah Peneliti (2019)

Dari data diatas disimpulkan bahwa :

c. Pengujian hipotesis ketiga (H3)

nilai signifikan untuk $\mathrm{X} 1$ produk dan $\mathrm{X} 2$ sebesar 0,000 lebih kecil dari $<0,05$ nilai $\mathrm{F}$ hitung 125,475 lebih besar dari > F tabel 3,35 jadi H3 diterima pengaruh X1 produk dan X2 harga secara simultan terhadap Y

\section{Koefesien Determinasi $\left(R^{2}\right)$}

\section{Analisis Data Koefesien Determinasi $\left(\mathbf{R}^{2}\right)$}

\begin{tabular}{|l|l|l|l|l|}
\hline & & & & \\
Model & $\mathrm{R}$ & R Square & Adjusted R Square & $\begin{array}{l}\text { Std. Error of the } \\
\text { Estimate }\end{array}$ \\
\hline 1 &, $950^{\mathrm{a}}$ &, 903 &, 896 & 1,148 \\
\hline
\end{tabular}

a. Predictors: (Constant), harga, produk

Sumber : Data Diolah Peneliti (2019)

koefesien $\mathrm{R}$ square 0,903.variabel independen secara simultan terhadap variabel dependen adalah sebesar $90,3 \%$ dan sisanya adalah $9,7 \%$. 


\section{Pembahasan}

Pada hasil bagian ini membahas pengaruh produk dan harga terhadap keputusan pembelian tas merk rumah warna di bandar lor kota kediri. Produk dan harga adalah salah satu faktor penting saat melakukan keputusan pembelian karena konsumen selalu melihat kualitas produk dan harga.

Hasil penelitian dan perhitungan manual serta dengan progam SPSS (Statistical Package For the Social Sciences) for Windows 22,0 dapat diketahui hasil pre-test hasil post-test mengalami peningkatan.hasil uji $\mathrm{t}$ pre-test dan post-test mempunyai nilai

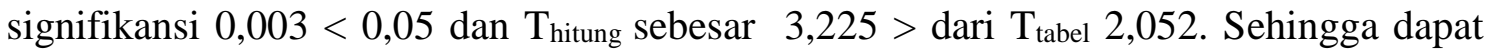
disimpulkan bahwa H1 diterima yang berati terdapat pengaruh variabel produk secara parsaial atau sendiri terhadap keputusan pembelian. Sedangkan variabel harga memiliki nilai signifikansi sebesar $0,011<0,05$ dan nilai $\mathrm{T}_{\text {hitung }} 2,731>$ dari $\mathrm{T}_{\text {tabel }} 2,052$. Sehingga dapat disimpulkan bahwa $\mathrm{H} 2$ diterima yang berpengaruh variabel harga secara parsial.H3 nilai signifikan 0,000 lebih kecil dari < 0,05 dan nilai $F_{\text {hitung }} 125,475$ lebih besar dari $>\mathrm{F}_{\text {tabel }}$ 3,35 berarti $\mathrm{H} 3$ diterima berpengaruh $\mathrm{X} 1$ produk dan $\mathrm{X} 2$ harga secara simultan pada keputusan pembelian Y.

\section{KESIMPULAN DAN SARAN}

\section{Kesimpulan}

Berdasarkan rumusan masalah dan hasil penelitian pengaruh produk dan harga terhadap keputusan pembelian tas merk rumah warna di bandar lor kota kediri hasil penelitiannya:

1. Terdapat pengaruh signifikan antara produk dan harga secara simultan terhadap keputusan pembelian tas merk rumah warna di bandar lor kota kediri. Hal ini dibuktikan dengan adanya hasil dari nilai $\mathrm{F}_{\text {hitung }} 125,475>\mathrm{F}_{\text {tabel }}$ 3,35 signifikan 0,000 lebih kecil dari $<0,05 \mathrm{H}_{0}$ ditolak dan $\mathrm{H}_{\mathrm{a}}$ diterima.

2. Produk berpengaruh secara parsial terhadap keputusan pembelian .

3. Harga berpengaruh secara parsial terhadap keputusan pembelian.

4. Besarnya pengaruh produk dan harga terhadap keputusan pembelian tas merk rumah warna di bandar lor kota kediri berdasarkan peningkatan sebesar 90,3\% dengan sisa $9,7 \%$. 


\section{Saran}

Berdasarkan kesimpulan diatas peneliti menyimpulkan saran sebagai beikut :

1. Berdasarkan hasil penelitian yang diperoleh antara variabel produk dan variabel harga berpengaruh terhadap keputusan pembelian variabel produk.

2. Produsen diharapkan lebih meningkatkan intensitas produk mengingat pengaruh produk yang lebih dominan dari harga saat meningkatnya volume penjualan.

3. Untuk meningkatkan volume penjualan diharapkan produsen lebih memperhatikan kebijakan harga dalam memasarkan produk.

\section{DAFTAR PUSTAKA}

Afif, rahmadi nur. (2015). analisis kualitas pelayanan, kualitas produk dan kenyamanan terhadap keputusan konsumen dalam menggunakan jasa sport center (studi kasus mensana sport center futsal kediri). KOMPILEK, 7(1), 37-45. Retrieved from http://journal.stieken.ac.id/index.php/kompilek/article/view/149

Ruhamak, M. D. (2016). Analisis faktor yang mempengaruhi konsumen dalam pengambilan keputusan pembelian produk air minum merk aqua. Jurnal EkoNika, 1(1), 38-49. Retrieved from http://ojs.unikkediri.ac.id/index.php/ekonika/article/view/4

Alma, buchari. 2013. Managemen Pemasaran dan Jasa, Penerbit alfabeta, Bandung.

Basu Swastha, Hani Handoko, 2011. Managemen Pemasaran-Analisis Perilaku Konsumen. Yogyakarta:BPFE.

Djamin Saladin, 2011, Intisari pemasaran dan unsur-unsur pemasaran, cetakan keempat, pencipta :Linda karya, Bandung.

Devi Anastasa.2015.Pengaruh citra merek,harga dan gaya hidup terhadap keputusan pembelian produk imitasi studi kasus pembelian tas imitasi louis vuitton pada mahasiswa fakultas ilmu sosial dan ilmu politik universitas diponegoro, Jurnal managemen Vol.2:Hal 10.

Fatmawati Asih.2016. pengaruh citra merek,kualitas produk, dan harga terhadap keputusan pembelian produk tas dan sepatu charles dan keith studi kasus konsumen charles dan keith paragon semarang, Jurnal pemasaran Vol.3:Hal 8.

Fandy Tjiptono, Ph.D.2015. stratergi pemasaran, edisi 4, Penerbit Andi, Yogyakarta.

Ghozali, Imam. 2011. Aplikasi Analisis Multivariate Dengan Progam SPSS. Semarang: Badan Penerbit Universitas Diponegoro.

Kotler, Keller dan Gary Armstrong. 2012. Prinsip-Prinsip Pemasaran. Edisi 12. Jilid 1. Terjemahan Bob Sabran. Penerbit Erlangga, Jakarta.

Kotler Philip, Armstrong Garry. 2013. Prinsip-Prinsip Pemasaran, Edisi ke-12. Penerbit Erlangga.

Sugiyono. 2014 Metode Penelitian Pendidikan Pendekatan Kuantitatif, Kualitatif,dan R\&D. Bandung : Eidos. 